\title{
Case report of atypical Still's disease: a diagnosis of exclusion
}

This article was published in the following Dove Press journal:

International Medical Case Reports Journal

19 October 2016

Number of times this article has been viewed

\section{Sandeep Yerra'}

Letlhogonolo Tlhabano ${ }^{2}$

Tejaswini Vasamsetty ${ }^{3}$

'Department of Anesthesiology, University of Virginia, Charlottesville, VA, ${ }^{2}$ Internal Medicine, Wake Forest Baptist Health, Winston-Salem, ${ }^{3}$ Internal Medicine, East Carolina University, Greenville, NC, USA
Correspondence: Sandeep Yerra 237 Yellowstone Drive, Apt 108, Charlottesville, VA, USA

Email drsandeepyerra@gmail.com
Introduction: We present an unusual presentation of a 39-year-old man with myalgias and shortness of breath.

Chief complaints: The patient presented to the emergency department with complaints of myalgias, shortness of breath and palpitations. During this hospitalization, he had multiple episodes of tachycardia and desaturation. The patient had elevated troponins and creatinine kinase. Differential diagnosis included pericarditis, pneumonia and malignancy.

Investigations: The patient had elevated ferritin and erythrocyte sedimentation rate.

Outcome: The patient had adult Still's disease.

Lesson: This case shows how the presentation and symptom complex of Still's disease together with the lack of specific serological markers can misguide the diagnosis.

Keywords: adult Still's disease, rheumatology, hemophagocytic lymphohistiocytosis, immunology

\section{Introduction}

We present an unusual case of a 39-year-old man who presented to the emergency department with myalgias, shortness of breath, palpitations and fever with chills. During this hospitalization, he had multiple episodes of tachycardia and desaturation. The patient had elevated troponins and creatinine kinase. Differential diagnosis included pericarditis, pneumonia and malignancy. The patient had elevated ferritin and erythrocyte sedimentation rate (ESR). This case shows how the presentation and symptom complex of Still's disease together with the lack of specific serological markers can misguide the diagnosis. Early recognition of the florid manifestations will shorten hospital stay and avoid putting the patient through a battery of tests.

\section{Case}

A 39-year-old African-American man with a past medical history of type 2 diabetes mellitus and hyperlipidemia presented with stiffness, generalized myalgias, shortness of breath and irregular heart beat. The patient reported that the symptoms had progressively worsened since onset ( $\sim 1$ week prior), which prompted him to seek emergent/ urgent medical care at the outside hospital. Here, he was treated for statin-induced rhabdomyolysis with ibuprofen, valium and vicodin and discharged home. After 3 days, he presented to our hospital with persistent and worsening myalgias (that were 4/10 in intensity). He also complained of stiffness that was more prominent in lower extremities, neck, shoulders and chest. Upon further history, he reported decreased oral fluid 
intake and 3-day history of dyspnea on exertion. Medication history was significant for discontinuation of statins 2 months ago. Review of symptoms was positive for non-productive cough of 2 weeks duration, fatigue and nausea. He denied experiencing similar symptoms in the past, recent travel or consumption of any over-the-counter or herbal medications. Past medical history included diabetes mellitus (diet controlled), hyperlipidemia and regular alcohol use ( 2 beers per day). Review of systems was positive for intermittent fever, trouble swallowing and flank pain. On examination, he was febrile (temperature $39.5^{\circ} \mathrm{C}$ ), tachycardic $(116 \mathrm{bpm})$, tachypneic $(30 \mathrm{cpm})$ and hypoxemic (requiring $4 \mathrm{~L}$ of oxygen to maintain oxygen saturation $>90 \%$ ). Diffuse tenderness was elicited in majority of the proximal muscle groups. He also had right parasternal chest tenderness and mild bilateral lower extremity swelling. Initial investigations showed a white cell count of 10.5 (absolute neutrophil count 9.4), normal basic metabolic panel, negative gram stain of urine, negative respiratory virus panel, normal procalcitonin and creatinine kinase of 208. Based on initial evaluation, he was given a preliminary diagnosis of pneumonia and was started on $1 \mathrm{~L}$ of normal saline, intravenous antibiotics (ceftriaxone and azithromycin) and $4 \mathrm{~L}$ of oxygen via nasal cannula to keep his saturation $>92 \%$. Infectious workup revealed a negative sepsis screen, sputum, urine cultures, mononuclear test and normal lactic acid. He continued to have high spiking fevers, arthralgia, persistent tachycardia, chest pain worsened with deep breathing and cramps in bilateral lower extremities. On further investigations, he was found to have elevated troponins and creatine kinase. Imaging performed to further evaluate the cause for shortness of breath included a negative chest X-ray and computed tomography angiography (CTA) chest concerning multilobar pneumonia. As this was consistent with sepsis, he was continued on ceftriaxone and azithromycin for community-acquired pneumonia. Pericarditis was ruled out with transthoracic echocardiogram, which showed normal cardiac function and absence of any effusions. Tachycardia was thought to be likely due to anxiety and was managed with alprazolam $2 \mathrm{mg} /$ pro re nata (PRN) or as needed. Infectious and autoimmune etiology were ruled out by the following tests: hepatitis panel, human immunodeficiency virus antibody, Epstein-Barr virus, mycoplasma antibodies, anti-nuclear antibodies, anti-neutrophil cytoplasmic antibodies, rheumatoid factor and anti-Jo-1 antibodies were negative. Elevated ferritin at 27,088 $\mathrm{ng} / \mathrm{mL}, \mathrm{ESR}$ at $105 \mathrm{~mL} /$ hour and C-reactive protein (CRP) at $344 \mu \mathrm{g} / \mathrm{L}$ were found. Patient continued to have persistent fevers. The search for a noninfectious etiology to explain the fever was sought out on day
6. Head and chest along with abdominal/pelvic CT showed no infectious etiology or evidence of malignancy. Hemophagocytic lymphohistiocytosis (HLH) can cause a similar level of hyperferritinemia to adult Still's disease (ASD) and was ruled out by the absence of leukopenia, lymphopenia and granulocytopenia. Also to be noted was the bone marrow biopsy that did not show any signs of hemophagocytosis. The patient continued to have aching sternal pain and tachycardia, raising concern for myocarditis with friction rub. He continued to have inconsistent fevers, episodes of desaturation and chest pain. He was started on colchicine and ibuprofen with transition to oral antibiotics. Based on elevated ferritin levels, persistent fevers and the lack of infectious foci, a diagnosis of adult-onset Still's disease was made. This diagnosis was discussed among infectious disease, rheumatology, hematology-oncology and general medicine departments. It was confirmed by the fact that patient responded well to steroids. He was started on $1 \mathrm{mg} / \mathrm{kg} /$ day of prednisone with resolution of symptoms 2 days after start of therapy. The total length of stay was 9 days. The patient was scheduled for regular follow-up every 2 weeks. We continued tapering doses of prednisone with the goal of $10 \mathrm{mg} /$ day at the end of 7 weeks. At the end of 8 weeks, the patient did not have any flares and complained of some mild joint pain occasionally. Over the next 3 months, the patient continued a maintenance dose of $10 \mathrm{mg}$ prednisone daily. He was seen in follow-up visits and was doing well with no complaints or flares. He was then gradually transitioned to the disease-modifying anti-rheumatic drug (DMARD) anakinra. Written informed consent was received from the patient.

\section{Discussion}

This case highlights the florid manifestations and challenges in diagnosing Still's disease. A patient presenting with quotidian fevers, evanescent rash and various types of arthritis is the typical presentation of ASD or systemic juvenile idiopathic arthritis. ${ }^{1}$ The etiology is currently proposed as a mix of genetic factors (human leukocyte antigen [HLA] - B17, HLA - B18, HLA - B35 and HLA - DR2) and infectious triggers (Rubella, Parvovirus B19, Yersinia enterocolitica). ${ }^{2-5}$ Still's is a rare disease (incidence of $0.16 / 100,000$ persons) with bimodal age distribution between ages 15-25 and 36-46. ${ }^{6}$ The disease has 3 presentations: monophasic type, intermittent type, and chronic articular type. Major presenting symptoms are quotidian fever, evanescent salmon colored rash and oligo- or poly-arthritis for all 3 types. ${ }^{7}$ Myalgia occurs with fever spikes and can be severe and debilitating. One of the characteristic symptoms seen in Still's disease 
is fusion of wrist joints. Other symptoms include a severe, non-suppurative pharyngitis (found in 69\% of cases), hepatomegaly (12-45\%), elevated transaminases (75\%), abdominal pain (1-48\%) and cardiopulmonary disease (30-40\%) such as pericarditis, pleural effusions and transient pulmonary infiltrates. Rarely renal, ophthalmic and neural involvement is also observed. Laboratory abnormalities include elevation of CRP, ESR and serum ferritin. Aspartate transaminase (AST) and alanine transaminase (ALT) are elevated with the disease and are further elevated upon the use of non-steroidal antiinflammatory drugs (NSAIDs) in the treatment. Hematologic manifestations include lymphocytosis with neutrophilia, normocytic normochromic anemia and thrombocytosis, microangiopathic hemolytic anemia, thrombotic thrombocytopenic purpura (TTP)-hemolytic-uremic syndrome (HUS) and disseminated intravascular coagulation (DIC). Diagnostic criteria of Still's disease are given in Table $1 .^{8-11}$

Monophasic type has a single flare of disease that lasts between weeks to months, and then the disease usually completely resolves. Intermittent type flares last between several weeks to 1 or 2 years with one or more disease flares, and this type completely resolves as well. Chronic articular type patients have a persistently active disease, which usually evolves from monophasic or intermittent type. Treatment options and classification of disease are given in Table 2.

Of the numerous complications of Still's disease, the most serious is HLH. HLH is a syndrome associated with excessive immune activation. Macrophages, natural killer cells and cytotoxic lymphocytes are excessively activated with inadequate or absent down regulation. HLH symptoms include hepatomegaly, lymphadenopathy, neurological manifestation

Table I Diagnostic criteria of Still's disease

Five of the following criteria should be met for a diagnosis of ASD. Two criteria must be major

Major criteria

I. Fever of at least $39^{\circ} \mathrm{C}\left(102.2^{\circ} \mathrm{F}\right)$ lasting at least I week

2. Arthralgias or arthritis lasting 2 weeks or longer

3. A non-pruritic macular or maculopapular skin rash that is salmon-colored in appearance and usually found over the trunk or extremities during febrile episodes

4. Leukocytosis ( $10,000 / \mu \mathrm{L}$ or greater), with at least $80 \%$ granulocytes Minor criteria

I. Sore throat

2. Lymphadenopathy

3. Hepatomegaly or splenomegaly

4. Abnormal liver function studies, particularly elevations in AST, ALT and LDH concentrations

5. Negative tests for ANA and RF

Abbreviations: ASD, adult Still's disease; AST, aspartate transaminase; ALT, alanine transaminase; LDH, lactate dehydrogenase; ANA, anti-nuclear antibody; RF, rheumatoid factor. and rash. In the presence of HLH along with ASD, an attempt should be made to treat ASD provided the patient is stable, as the treatment of HLH involves drugs with many side effects including dexamethasone, etoposide, methotrexate and in some cases cyclosporine. In an unstable patient, therapy should be directed toward resolving HLH. It is also prudent to remember that NSAIDs used in the treatment of ASD are one of the potential triggers of MAS. MAS is a rare

Table 2 Classification of Still's disease and treatment options

\begin{tabular}{|c|c|c|c|}
\hline Type & $\begin{array}{l}\text { Clinical } \\
\text { features }\end{array}$ & Treatment & Dosage \\
\hline $\begin{array}{l}\text { Mild } \\
\text { disease }\end{array}$ & $\begin{array}{l}\text { Fever, rash, } \\
\text { arthralgia or } \\
\text { mild arthritis }\end{array}$ & $\begin{array}{l}\text { Start with } \\
\text { NSAIDs alone. } \\
20 \% \text { respond } \\
\text { to this alone. } \\
\text { Add low-dose } \\
\text { glucocorticoids if } \\
\text { symptoms control } \\
\text { is not achieved in } \\
10-14 \text { days. Only } \\
20 \% \text { respond to } \\
\text { NSAIDs alone. }\end{array}$ & $\begin{array}{l}\text { Naproxen } 500 \mathrm{mg} \\
\mathrm{BD} \text {, ibuprofen } \\
800 \mathrm{mg} \text { TD or QID. } \\
\text { Reduce doses as } \\
\text { symptoms resolve } \\
\text { and continue for } \\
2-3 \text { months. No } \\
\text { DMARDs }\end{array}$ \\
\hline $\begin{array}{l}\text { Moderate } \\
\text { disease }\end{array}$ & $\begin{array}{l}\text { High fevers, } \\
\text { debilitating } \\
\text { joint } \\
\text { symptoms, } \\
\text { internal } \\
\text { organ } \\
\text { involvement } \\
\text { that is } \\
\text { not life } \\
\text { threatening } \\
\text { or severe }\end{array}$ & $\begin{array}{l}\text { Start with } \\
\text { glucocorticoids to } \\
\text { control symptoms } \\
\text { and inflammatory } \\
\text { response. } \\
\text { Responds within } \\
\text { hours to few } \\
\text { days. DMARDs } \\
\text { for long-term } \\
\text { management } \\
\text { or when } \\
\text { symptoms recur } \\
\text { or cannot be } \\
\text { controlled } \\
\text { on tapering } \\
\text { glucocorticoids. } \\
70 \% \text { respond to } \\
\text { glucocorticoid } \\
\text { alone. }\end{array}$ & $\begin{array}{l}\text { Prednisone } 0.5 \mathrm{mg} \\
\text { to I mg/kg. Rapidly } \\
\text { taper and maintain } \\
\text { at low dose for } \\
2-3 \text { months even } \\
\text { when symptoms } \\
\text { are controlled. } \\
\text { DMARDs anakinra } \\
\text { for primarily } \\
\text { systemic disease. } \\
\text { Methotrexate for } \\
\text { primarily articular } \\
\text { disease. Taper after } \\
\text { patient is stable for } \\
4-6 \text { months starting } \\
\text { with glucocorticoid } \\
\text { and then DMARD. }\end{array}$ \\
\hline $\begin{array}{l}\text { Severe } \\
\text { disease }\end{array}$ & $\begin{array}{l}\text { Life- } \\
\text { threatening } \\
\text { organ } \\
\text { involvement } \\
\text { and/or } \\
\text { severe } \\
\text { hepatic } \\
\text { involvement, } \\
\text { cardiac } \\
\text { tamponade, } \\
\text { DIC }\end{array}$ & $\begin{array}{l}\text { Start with } \\
\text { high-dose pulse } \\
\text { glucocorticoids } \\
\text { and anakinra. Add } \\
\text { methotrexate in } \\
\text { patients who have } \\
\text { ongoing arthritis } \\
\text { or develop } \\
\text { erosive arthritis. } \\
\text { Consider } \\
\text { prophylactic } \\
\text { antibiotics for } \\
\text { pneumocystis } \\
\text { pneumonia. }\end{array}$ & $\begin{array}{l}\text { Methylprednisolone } \\
\text { I,000 mg } \\
\text { intravascular daily } \\
\text { for } 3 \text { days. Followed } \\
\text { by oral prednisone } \\
60 \mathrm{mg} \text { and } \\
\text { anakinra } 100 \mathrm{mg} \\
\text { subcutaneous daily. } \\
\text { Taper prednisone } \\
\text { as tolerated } \\
\text { with the goal of } \\
\text { discontinuing it in } \\
2-4 \text { months }\end{array}$ \\
\hline
\end{tabular}

Abbreviations: NSAIDs, non-steroidal anti-inflammatory drugs; DMARDs, disease-modifying anti-rheumatic drugs; DIC, disseminated intravascular coagulation. 
complication of ASD and falls within the spectrum of HLH. It is similar to HLH in manifestations, but it usually arises as a complication of ASD and fulfills Yamaguchi classification criteria for Still's disease. ${ }^{12-14}$

Prognosis is generally good for patients suffering from ASD with $90 \%$ of the patients being able to perform daily activities even when they are suffering from chronic type disease. Immediate identification of ASD is very important. The presentation and complications of the disease are florid. High index of suspicion for the characteristic signs and symptoms will help in early identification and reduce a great amount of discomfort. We suggest a classification of the patient based on disease severity and immediate treatment to reduce the rate of complications. This presentation is unique with pneumonia, myalgias and tachycardia as prominent symptoms. As a result, a search for other possible etiologies explaining the patient symptoms was carried out. This illustrates the point that Still's disease with its complications is still a diagnostic conundrum in spite of well-researched diagnostic guidelines. Physicians should be aware of this kind of presentation with pneumonia and tachycardia.

\section{Acknowledgment}

The authors did not receive any funding for this case report.

\section{Disclosure}

The authors report no conflicts of interest in this work.

\section{References}

1. Bywaters EG. Still's disease in the adult. Ann Rheum Dis. 1971;30(2): 121-133.

2. Wouters JM, van der Veen J, van de Putte LB, de Rooij DJ. Adult onset Still's disease and viral infections. Ann Rheum Dis. 1988;47(9):764-767.

3. Huang SH, DeCoteau WE. Adult-onset Still's disease: an unusual presentation of rubella infection. Can Med Assoc J. 1980;122(11): $1275-1276$.

4. Ueno Y, Umadome H, Shimodera M, Kishimoto I, Ikegaya K, Yamauchi T. Human parvovirus B19 and arthritis. Lancet. 1993;341(8855):1280.

5. Colebunders R, Stevens WJ, Vanagt E, Snoeck J. Adult Still's disease caused by Yersinia enterocolitica infection. Arch Intern Med. 1984; 144(9):1880-1882.

6. Magadur-Joly G, Billaud E, Barrier JH, et al. Epidemiology of adult Still's disease: estimate of the incidence by a retrospective study in west France. Ann Rheum Dis. 1995;54(7):587-590.

7. Pouchot J, Sampalis JS, Beaudet F, et al. Adult onset Still's disease: manifestations, disease course and outcome in 62 patients. Medicine (Baltimore). 1991;70(2):118-36.

8. Kontzias A, Efthimiou P. Adult-onset Still's disease: pathogenesis, clinical manifestations and therapeutic advances. Drugs. 2008;68(3): 319-337.

9. Gerfaud-Valentin M, Maucort-Boulch D, Hot A, et al. Adult-onset still disease: manifestations, treatment, outcome, and prognostic factors in 57 patients. Medicine (Baltimore). 2014;93(2):91-99.

10. Yamaguchi M, Ohta A, Tsunematsu T, et al. Preliminary criteria for classification of adult Still's disease. J Rheumatol. 1992;19(3):424.

11. Gerfaud-Valentin M, Jamilloux Y, Iwaz J, Sève P. Adult-onset Still's disease. Autoimmun Rev. 2014;13(7):708-722.

12. Jordan MB, Allen CE, Weitzman S, Filipovich AH, Mcclain KL. How I treat hemophagocytic lymphohistiocytosis. Blood. 2011;118(15): 4041-4052.

13. Morris JA, Adamson AR, Holt PJ, Davson J. Still's disease and the virus-associated haemophagocytic syndrome. Ann Rheum Dis. 1985; 44(5):349-353.

14. Ravelli A. Macrophage activation syndrome. Curr Opin Rheumatol. 2002;14(5):548-552.
International Medical Case Reports Journal

\section{Publish your work in this journal}

The International Medical Case Reports Journal is an international, peer-reviewed open-access journal publishing original case reports from all medical specialties. Previously unpublished medical posters are also accepted relating to any area of clinical or preclinical science. Submissions should not normally exceed 2,000 words or

\section{Dovepress}

4 published pages including figures, diagrams and references. The manuscript management system is completely online and includes a very quick and fair peer-review system, which is all easy to use. Visit http://www.dovepress.com/testimonials.php to read real quotes from published authors. 